\title{
Percepções sobre animalidade e natureza em narrativas apócrifas do cristianismo primitivo
}

\author{
Perceptions about animality and nature in early \\ Christian apocryphal narratives
}

\section{Percepciones sobre la animalidade y la naturaleza en las narrativas apócrifas del cristianismo primitivo}

\author{
Guilherme de Figueiredo Cavalheri*
}

\begin{abstract}
RESUMO
O presente artigo tem por objetivo analisar o papel dos animais na literatura apócrifa do cristianismo primitivo. Apesar de significativa parte da tradição cristã relegar aos animais um papel meramente simbólico e alegórico, sugerimos que, nas fontes apócrifas, marcadas pela presença de temas e tradições folclóricas, os animais possuem lugar destacado como agentes religiosos. Para isso, serão analisados episódios presentes nos chamados Evangelhos Apócrifos da Infância e nos Atos Apócrifos dos Apóstolos, tomando como ponto de partida intuições da antropologia perspectivista. Nossa hipótese é que, em tais materiais, é possível acessar elementos de uma percepção de mundo na qual as fronteiras entre o humano e o extra-humano são maleáveis e circunstanciais.
\end{abstract}

Palavras-chave: Apócrifos; animais; natureza; folclore; perspectivismo.

\begin{abstract}
This article aims to analyze the role of animals in the early Christian apocryphal literature. Although a significant part of the Christian tradition relegates animals to purely symbolic and allegorical roles, we suggest that, in apocryphal sources, marked by the presence of folkloric themes and traditions, animals have a prominent place as religious agents. For this, episodes present in the so-called Apocryphal Gospels of Childhood and in the Apocryphal Acts of the Apostles will be analyzed, taking as a starting point intuitions from the Perspectivist Anthropology. Our hypothesis is that, in such materials, it is possible to access elements of a worldview in that boundaries between the human and the extrahuman are malleable and circumstantial.
\end{abstract}

Keywords: Apocrypha; animals; nature; folklore; perspectivism.

\section{RESUMEN}

Este artículo tiene como objetivo analizar el papel de los animales en la literatura apócrifa del cristianismo primitivo. Aunque una parte importante de la tradición cristiana relega a los animales a un papel puramente simbólico y alegórico, sugerimos que, en fuentes apócrifas, marcadas por la presencia de temas y tradiciones populares, los animales tengan un lugar destacado como agentes religiosos. Para ello, se analizarán episodios presentes en los llamados Evangelios apócrifos de la infancia y en los Hechos apócrifos de los apóstoles, tomando

* Graduado em História pela Universidade Estadual Paulista e Teologia pela Faculdade de Teologia de São Paulo da Igreja Presbiteriana Independente do Brasil, mestre em Ciências da Religião pela Universidade Metodista de São Paulo (Umesp). Atua na área de Linguagens da Religião, com ênfase em Religião e Literatura no Mundo Bíblico. 
como punto de partida las intuiciones desde la Antropología Perspectivista. Nuestra hipótesis es que, en dichos materiales, es posible acceder a elementos de una percepción del mundo en el que los límites entre lo humano y lo extrahumano son maleables y circunstanciales.

Palabras clave: Apócrifos; animales; naturaleza; folklore; perspectivismo.

\section{Introdução: repensando humanos e não-humanos na religião}

Não é de hoje que os debates a respeito da crescente crise ambiental que nos afeta têm se acirrado e se espraiado por diferentes áreas do conhecimento. Fora do âmbito ecológico da discussão, a referida crise se expande para além das questões a respeito do uso consciente de recursos naturais, da sustentabilidade ambiental e do uso de fontes de energia limpas. O que se desvela por detrás de todas essas questões é o colapso de um projeto humanístico-desenvolvimentista, perpetrado pelas grandes nações ocidentais desde o início da Modernidade.

De acordo com Alexandre Nodari, se a condição pós-moderna, tal como pensada por Jean-François Lyotard, é identificada como a "crise dos grandes relatos", uma consequência incontornável dessa condição pode ser a da crise do "grande Relator". Dito de outra maneira, não é apenas a grande narrativa de desenvolvimento econômico, técnico e científico da modernidade que entra em convulsão, mas também a identidade e autoafirmação do ser humano moderno que narra sua própria epopeia (NODARI, 2015, p. 7576). A visão moderna do mundo, ao mesmo tempo ferramenta e commodity à disposição humana, se desenvolve paralelamente à imagem do próprio ser humano, dissociado da Natureza enquanto consciência de si.

Ainda segundo Nodari, na modernidade, o ser humano se apresenta como ser "extraterrestre", cuja existência se dá fora da Natureza, a partir da progressiva construção do mito do excepcionalismo humano que, por não se identificar como organismo componente de seu entorno, o suplanta e o modifica segundo suas próprias aspirações (NODARI, 2015, p. 77). O assim chamado Antropoceno, era geológica identificada pela intensa e agressiva ação humana na superfície terrestre, é resultado de uma concepção do humano que se mantém em andamento em nosso tempo.

Há algumas décadas, os estudos culturais têm se dedicado a pensar a questão a partir da discussão a respeito de uma cláusula pétrea da filosofia moderna: a relação entre Natureza e Civilização ou, na linguagem antropológica, Natureza e Cultura. Se a antropologia evolucionista do início do século passado dedicou-se a analisar as sociedades primitivas e tradicionais partindo do prisma do desenvolvimento civilizacional (ou seja, a partir de diferentes 
estágios de evolução cultural), a antropologia contemporânea tem buscado no caminho inverso meios para a compreensão de nosso próprio drama ambiental. Para isso, é necessário repensar o lugar do ser humano no mundo, questionando a excepcionalidade e superioridade humanas sobre a Natureza.

Esse questionamento ganhou força, em diversos focos de discussão, a partir de meados do século passado. No caso da antropologia, o estudo das sociedades ameríndias foi importante para o início de uma importante revisão epistemológica na área. Ao analisar tais sociedades, percebeu-se que, entre o que tradicionalmente considerava-se como objetos "culturais" (instituições, tabus, representações simbólicas e rituais, organização social e percepções cosmológicas) e os "naturais" (espaços, animais e demais entes "não-humanos"), havia zonas neutras, cujos elementos pertenciam a ambas instâncias. Essas zonas foram desconsideradas no pensamento ontológico ocidental moderno, justamente pelo distanciamento que o ser humano tomou em relação à própria Natureza, vista agora como um mecanismo a ser decodificado e aperfeiçoado, cujos componentes são apenas utensílios às ciências e à técnica (DESCOLA, 2016, p. 23). A "antropologia perspectivista", portanto, pode ser sintetizada como um esforço de compreensão a respeito das cosmologias ameríndias, a partir da uma noção "relacional de natureza". Contudo, essa abordagem não se limita ao estudo das sociedades indígenas.

De acordo com Eduardo Viveiros de Castro, a divisão entre Natureza e Cultura, tal como se convencionou no pensamento ocidental moderno, se ampara em uma matriz metafísica que não corresponde àquela que se expressa em numerosos povos, o que resulta em nossa incompreensão (ou pior, má compreensão) da relação dessas sociedades com o mundo natural. Isso requer, portanto, uma séria revisão do nosso modo de enxergá-las:

Tal crítica, no caso presente, impunha a redistribuição dos predicados subsumidos nas duas séries paradigmáticas da "Natureza" e da "Cultura": universal e particular, objetivo e subjetivo, físico e moral, fato e valor, dado e instituído, necessidade e espontaneidade, imanência e transcendência, corpo e espírito, animalidade e humanidade etc. Esse reembaralhamento das cartas conceituais levou-me a sugerir a expressão "multinaturalismo" para designar um dos traços contrastivos do pensamento ameríndio em relação às cosmologias "multiculturalistas" modernas: enquanto estas se apoiam na implicação mútua entre unicidade da natureza e multiplicidade das culturas - a primeira garantida pela universalidade objetiva dos corpos e da substância, a segunda gerada pela particularidade subjetiva dos espíritos e dos significados -, a concepção ameríndia suporia, ao contrário, uma unidade do espírito e uma diversidade de corpos. A "cultura" ou o sujeito seriam aqui a forma universal, a "natureza" ou o objeto, a forma particular (VIVEIROS DE CASTRO, 2018, p. 43). 
O que Viveiros de Castro está propondo é que, em certas sociedades, a distinção entre objetos naturais e culturais, tal como a conhecemos, não faz sentido. Categorias que normalmente relacionamos a objetos naturais e culturais, nessas sociedades, mudam radicalmente de posição. Nelas, humanos e não-humanos partilham de características comuns importantes e, a depender das circunstâncias e de suas relações, se alternam na forma como são percebidos. Philippe Descola nos oferece um exemplo claro de como essa percepção funciona. Vejamos:

Para centenas de tribos amazônicas, que falam línguas diferentes, os não humanos também são pessoas que participam da vida social, pessoas com que podemos estabelecer relações de aliança ou, ao contrário, relações de hostilidade e de competição. [...] Do mesmo jeito que os índios da Amazônia, os índios do Grande Norte canadense consideram a maioria dos animais como pessoas que possuem uma alma e, portanto, dotadas de diversas qualidades humanas, em particular o senso de solidariedade, de amizade e de respeito aos mais velhos. [...] Isso nos faz questionar nossa maneira de conceber a relação dos humanos com os animais e as plantas. Somos tentados a achar que essa maneira de pensar é universal, mas, evidentemente, ele não é (DESCOLA, 2016, p. 14-15, 18).

O questionamento em torno do binômio "Natureza-Cultura" não se deu apenas na observação das sociedades indígenas. Todos os híbridos que nos rodeiam se encontram na "zona cinzenta" apontada por Descola: dos softwares de inteligência artificial, aos robôs antropomórficos e mesmo os animais de estimação se encontram nesse "meio do caminho".

Essas reflexões têm possibilitado outros olhares, inclusive, sobre o fenômeno religioso. Apesar de a antropologia cultural, especialmente a de orientação estruturalista, ter tomado as mitologias ameríndias como fonte de sua reflexão a respeito do Multinaturalismo indígena (afinal, é a partir do mito que se opera essa transitoriedade entre o humano e o não-humano), é na filosofia que a questão é pensada de modo mais amplo. Não é por acaso que Georges Bataille abre sua Teoria da Religião com uma discussão a respeito da relação entre o animal e o mundo. Animais, assim como as plantas, não possuem autonomia diante do mundo, mas se situam nele a partir de relações de imanência. Para Bataille, o animal é como "água na água”, ou seja, não há uma separação clara entre si e os demais organismos que compõem o seu mundo (BATAILLE, 2016, p. 24).

Animais que devoram suas presas, portanto, não o fazem por qualquer relação de objetificação do mais forte sobre o mais fraco, pois "não há, do animal comido àquele que come, uma relação de subordinação como aquela que liga um objeto, uma coisa, ao homem que, ele, se recusa a ser considerado 
como uma coisa" (BATAILLE, 2016, p. 24). Para pensar a origem da religião, Bataille toma como ponto de partida a relação imanente e inseparável entre o animal e seu mundo, destacando a diferença dessa relação quanto à do ser humano que, deslocado de sua condição animal (e consciente disso), baseia sua relação com os elementos do mundo a partir de sua utilidade.

A "ferramenta", diz o filósofo, "introduz a exterioridade num mundo onde o sujeito participa dos elementos que ele distingue, onde ele participa do mundo e nele permanece como 'água na água" (BATAILLE, 2016, p. 29, grifos do autor). O emprego humano da ferramenta, portanto, desloca o objeto do mundo no qual ele participa integralmente. Ao lhe dar uma utilidade, o ser humano o retira de seu espaço e rompe suas relações com os demais objetos, impondo a estes uma condição de subordinação àquele objeto tornado ferramenta humana. Ao mesmo tempo, o ser humano é modificado pela própria ferramenta, e à medida em que submete a Natureza ao seu uso, ele próprio se aliena a ela:

A natureza se torna a propriedade do homem, mas cessa de lhe ser imanente. Torna-se dele sob a condição de lhe estar fechada. Se o homem coloca o mundo em seu poder, é na medida em que esquece que ele próprio é o mundo: nega o mundo, mas ele próprio é negado. Tudo aquilo que está em meu poder anuncia que reduzi o que é semelhante a mim a não existir mais para seu próprio fim, mas para um fim que lhe é estranho (BATAILLE, 2016, p. 37).

De acordo com Bataille, o sagrado se manifesta no ser humano a partir da consciência de sua imanência e no processo de seu deslocamento do mundo dos objetos. Algo, talvez, correlato à passagem da Natureza à Cultura que, como já vimos acima, tem sido problematizada na discussão etnológica. Por isso, Bataille aponta a experiência do ser humano "primitivo" diante dos animais, que ilustra muito bem esse fascínio e terror diante do sagrado:

Tudo indica que os primeiros homens estavam mais perto que nós do animal; talvez o distinguissem de si mesmos, mas não sem uma dúvida mesclada de terror e nostalgia. [...] Esse horror é ambíguo. Sem dúvida alguma, aquilo que é sagrado atrai e possui um valor incomparável, mas no mesmo instante parece vertiginosamente perigoso para esse mundo claro e profano onde a humanidade situa seu domínio privilegiado (BATAILLE, 2016, p. 34).

Nessa fresta por onde o humano enxerga o mundo imanente, as existências só podem ser diferenciadas parcialmente. São animais, plantas, estrelas, espíritos... habitantes do universo religioso do qual o humano tem parte, mas não tem controle. Ao qual ele se vê ligado, mas também distinto. A experi- 
ência religiosa, portanto, o recoloca a vislumbrar essa interconectividade de seres: "Os animais, as plantas, as ferramentas e as outras coisas manejáveis formam com os corpos que os manejam um mundo real, submetido e atravessado por forças divinas..." (BATAILLE, 2016, p. 36). Postulamos, portanto, a possibilidade de uma ambiguidade em relação ao judaísmo e ao cristianismo.

\section{Ambiguidades animais no judaísmo antigo e no cristianismo primitivo}

Historicamente, os animais ocupam um lugar dúbio na tradição cristã. Das leis dietéticas do Levítico às poderosas imagens da apocalíptica judaica; dos símbolos e alegorias para ideias religiosas à atuação narrativa como personagens, os animais estão lá, habitando os textos sagrados. De modo geral, as religiões de tradição abraâmica partem de um ponto mais ou menos comum sobre a relação entre humanos e animais. Judaísmo, Cristianismo e Islã partilham (a despeito de suas muitas ramificações) de um "antropocentrismo ético", ou seja, um foco na espécie humana como objeto de proteções morais fundamentais. Mesmo assim, em diferentes contextos, se desenvolveu no seio dessas religiões insights a respeito de uma moral quanto à vida dos animais, também dos limites do uso instrumental de diversas espécies pelos seres humanos (WALDAU, 2005, p. 70).

O relato da criação em Gênesis $1^{1}$ parece ser a pedra fundamental para uma compreensão comum que, se não é a única, tem sido majoritária ao longo de toda a tradição cristã: a de que os seres humanos são uma categoria separada e superior aos demais seres viventes, sobre os quais Deus submeteu o domínio humano. Retomando Bataille, a Natureza e, especificamente, os animais, são "ferramenta" nas mãos dos humanos, classificados segundo sua finalidade e utilidade. São, portanto, "bons" ou "maus" para se comer, para se sacrificar, para simbolizar e representar.

A partir do século I da Era Comum, esse tipo de representação foi potencializado por duas frentes. Por um lado, o debate a respeito da racionalidade animal iniciado por Aristóteles e, nos séculos seguintes, protagonizado por estoicos e médio-platônicos foi decisivo para o posicionamento judeu e cristão a respeito dos textos sagrados que tratavam diretamente da questão animal. Outro fator foi a inauguração da exegese alegórica por Filo de Alexandria, a partir da qual os animais representados na Torá foram associados à natureza corrompida pelo pecado. Nessa perspectiva, o mandato de Deus ao primeiro homem era, também, uma alegoria sobre o domínio da natureza

\footnotetext{
Os textos e menções à Bíblia são citados de obras que constam na bibliografia.
} 
caída e de sua separação em relação a ela.

A interpretação alegórica de Filo teve importante recepção nos primeiros escritores patrísticos, desde os escritos dos Pais Apostólicos até Santo Agostinho. A representação animal é vista, em geral, como negativa, mas obtém algumas nuances de texto para texto. Na Epistola de Barnabé, por exemplo, o caráter negativo dos animais é potencializado a ponto de relacionar a superioridade dos humanos sobre as criaturas com a superioridade dos cristãos sobre os não-cristãos. Ao mesmo tempo, em sua Primeira Carta aos Coríntios, Clemente de Roma evoca a coparticipação de humanos e animais nas bênçãos de Deus como um ideal de unidade a ser almejado pelos fiéis daquela igreja (CAVALHERI, 2019, p. 105-111).

Ao que parece, essa interpretação negativa sobre os animais se ampara principalmente na concepção aristotélica do Anima. Tanto os homens quanto os animais, segundo Aristóteles, eram dotados de alma. Entretanto, a alma humana é racional, diferente da alma animal. Ainda que partilhando da mesma natureza, os humanos se encontram em um patamar superior aos animais que, por isso, à semelhança dos escravos, eram considerados como órganon, "instrumentos" (SUSIN; ZAMPIERI, 2016, p. 77). Agostinho se aproxima tanto dessa concepção quanto da hierarquia das criaturas, herdada do neoplatonismo. A superioridade humana sobre o animal, na obra de Agostinho, também passa pela questão da racionalidade e pela disposição deles aos usos humanos, conforme apontam Susin e Zampieri:

O que instaura a diferença natural, para Agostinho, entre humanos e animais não humanos é a racionalidade, e a ausência desta nos animais não humanos os torna dependentes, inferiores e ao dispor dos humanos, fora da comunidade moral, podendo estes valerem-se das suas vidas sem nenhum sentimento de culpa do ponto de vista moral, até o extremo da morte (SUSIN; ZAMPIERI, 2016, p. 87).

Como afirmamos acima, a presença animal na tradição cristã é ambígua. Isso pode ser ilustrado tanto pelas correntes que tomam os conceitos da herança grega para afirmar a diferença ontológica e ética dos humanos sobre as outras criaturas quanto pelas tradições antigas que interpretam a presença animal de modo positivo e integrado à humanidade. Aqui, a apocalíptica judaica parece ter desempenhado um papel importante. Apesar de encontrarmos nos textos apocalípticos imagens tanto positivas quanto negativas dos animais, há uma diferença fundamental em relação às tradições que acabamos de enunciar. Aqui, os animais não são meras alegorias, mas símbolos poderosos e, por vezes, personagens que encarnam nas narrativas visionárias uma espécie de "agência divina" diante dos seres humanos. 
De acordo com Christopher R. Matthews (1999, p. 210-212), além da questão legal referente aos animais, a zoologia da Bíblia Hebraica fornece materiais importantes para a fundamentação da compreensão que certos grupos tiveram dos animais e da Natureza no cristianismo dos primeiros séculos da Era Comum. Em primeiro lugar, além da presença animal no âmbito das discussões sobre pureza contidas na Torá, certas narrativas já deixam entrever uma visão alternativa àquela que se tornou majoritária na história da interpretação bíblica. Existem, portanto, fissuras no "antropocentrismo ético" que marca a tradição judaico-cristã.

O texto paradigmático apontado por Matthews é o de Nm 22.21-35. $\mathrm{Na}$ pequena narrativa, o profeta Balaão segue a caminho da terra dos amorreus, onde os israelitas haviam se instalado. Junto à comitiva dos príncipes de Moab, é dada ao profeta a tarefa de amaldiçoar os israelitas, a fim de que seus adversários obtivessem vitória sobre eles. O anjo de Iahweh se coloca no caminho de Balaão, porém, apenas a jumenta que o carregava enxerga o anjo e, por isso, se retira da estrada. Por três vezes Balaão se irrita com o animal e o castiga com golpes de bordão. Com fala concedida pelo próprio Iahweh, a jumenta se queixa dos castigos do profeta, e se segue um diálogo entre os dois, que é interrompido pelo anjo que se revela ao profeta, anunciando que a prudência do animal havia salvado sua vida e, por isso, o castigo imposto à sua montaria era injustificado.

Alguns pontos chamam a atenção nesse texto, a começar pela reação de Balaão à fala da jumenta. O profeta prontamente responde ao questionamento de sua montaria, sem demonstrar espanto algum. Pelo contrário, Balaão entende que a atitude do animal fora consciente, como uma forma de zombar de si ou de atrapalhar os seus planos (v. 28). Outro ponto é o do reconhecimento do anjo pela jumenta. Ao responder, o anjo afirma que a jumenta é quem salvou a vida de Balaão, e mesmo se não o tivesse feito ao mudar de caminho, ele a deixaria com vida (v. 33). Que tipo de subtexto há em uma narrativa como essa? Segundo Matthews,

Números 22:21-35 é importante não só porque retrata um animal falante, mas também porque isso implica em uma habilidade nata sobre parte dos animais em perceber o divino. [...] Em outros lugares do cânon bíblico, as visões proféticas de um tempo messiânico sugerem não apenas uma coexistência pacífica entre vários membros do reino animal, mas também relações compassivas entre a humanidade e os animais [assim como em Isaías 11.6-9]. Os escritores do Novo Testamento oferecem mais que apenas afirmações indiretas concernentes à presença de animais na história da salvação. A localização do recém-nascido Jesus "em uma manjedoura" implicaria a presença de animais em seu nascimento, mas o texto não diz isso. Olhos cristãos piedosos descobriram posteriormente uma referência a tais animais em Isaías 1:3. A obscura referência às bestas selvagens em Marcos 1:13 talvez represente um cumprimento proléptico da paz escatológica anunciada pelos profetas (MATTHEWS, 1999, p. 212, tradução nossa). 
Temos aqui o desenvolvimento de um imaginário no qual as fronteiras entre o humano e o não-humano parecem se perder na experiência visionária. A linguagem mítica presente na apocalíptica judaica parece ser um terreno fértil para experimentos literários nos quais categorias ontológicas são suplantadas pela própria experiência religiosa. Um fenômeno que terá ressonâncias poderosas na literatura cristã a partir do segundo século, como veremos mais à frente.

Um exemplo interessante é o de 1 Enoque, na seção conhecida como Apocalipse Animal. A narrativa apresenta um relato do início da história da salvação, a partir de uma visão que Enoque recebe em um sonho, e que comunica ao seu filho Matusalém. O relato se inicia com uma descrição dos momentos iniciais da história, logo após a criação do mundo. Enoque relata que, em seu leito, Deus o levou a ver um touro branco que saía da terra, junto a bezerros, novilhos e outros touros de diversas cores. Em seguida, "um astro caía do céu, se levantava, comia e pastava com aqueles touros" (86.1). Após o primeiro astro cair (talvez os anjos Samiaza ou Azazel), muitos outros também se precipitaram à terra, pastando junto às novilhas e touros - "os olhei e vi que tinham membros eretos como cavalos e começaram a cobrir as novilhas das vacas, e todas se emprenharam e pariram elefantes, camelos e asnos" (86.3-4).

Os touros, com medo do que as estrelas estavam fazendo, começam a se agitar e a devorar os chifres uns dos outros, até que as próprias estrelas começassem a devorá-los. A visão de Enoque segue com a descida de sete homens brancos do céu, que o levam a contemplar, do alto de uma torre, o que aconteceria com os elefantes, camelos e asnos. A esses animais os homens brancos entregam uma espada e, reunindo à força todos os astros, os prendem em um desfiladeiro da terra (87-88). O que se segue no último capítulo dessa seção é a reelaboração da história das origens do povo de Israel, tendo como personagens uma variedade de animais.

A arca do dilúvio é construída por um touro branco que se metamorfoseia em humano (89.1); a estória dos Patriarcas é contada da perspectiva de um outro touro que, vivendo entre diversos animais (lobos, hienas, javalis, corvos etc.), gerou uma prole de várias espécies, primeiro um burro, depois um javali negro e por fim uma ovelha branca, esta gerou doze cordeiros que cresceram entre os lobos que os oprimiam. Como resposta, os cordeiros clamaram a Deus por sua libertação (89.10-20). Segue-se a narrativa do êxodo com a caminhada das ovelhas pelo deserto, lideradas por uma "ovelha

2 Na tradução de F. Corrente e A. Piñero para a edição de Diez Macho (1984), essa seção se encontra entre os capítulos 85 e 90 de 1 Enoque. 
feita homem" (89.21-40). As seções seguintes apresentam outros episódios da história da salvação, passando pelo exílio, o começo do reino messiânico, até a nova Jerusalém. A visão se encerra com os animais reunidos em uma grande casa e se transmutando todos em touros brancos, liderados por um grande boi de chifres negros (90.28-42).

Apesar de os animais representarem personagens e instituições da própria história de Israel, não é por acaso que existam categorias específicas de animais para assumir esses papeis. Além disso, o tema da metamorfose é importante, pois alguns desses animais assumem formas humanas, a fim de realizarem algum propósito. No caso de Noé, o boi se transforma em homem para construir a arca e, em Moisés, é a ovelha que se transforma para subir ao monte do Senhor. Especialmente no início da seção, temos certas categorias de seres que assumem formas e funções variadas de acordo com as circunstâncias que a narrativa apresenta para seu desenvolvimento.

A interpretação tradicional do Apocalipse Animal de 1 Enoque reside na alegoria histórica. As categorias de animais que representam as nações estrangeiras no texto são reaproveitadas e reelaboradas na Epistola de Barnabé para tratar da relação entre cristãos e gentios. Qual a razão, então, de um enredo tão bem conhecido até o segundo século antes da Era Comum ser reelaborado com personagens animais? Se conseguirmos vencer a tentação da alegorização, poderemos nos aproximar da narrativa com outros olhares.

Segundo Viveiros de Castro, é na linguagem mitológica que reside a condição de "ainda-inseparabilidade" entre humanos e não-humanos:

As narrativas míticas são povoadas de seres cuja forma, nome e comportamento misturam atributos humanos e não-humanos, em um contexto comum de intercomunicabilidade idêntico ao que define o mundo intra-humano atual. O perspectivismo ameríndio conhece então no mito um lugar, geométrico por assim dizer, onde a diferença entre os pontos de vista é ao mesmo tempo anulada e exacerbada. Nesse discurso absoluto, cada espécie de ser aparece aos outros seres como aparece para si mesma - como humana -, e, entretanto, age como se já manifestando sua natureza distintiva e definitiva de animal, planta ou espírito. [...] o mito fala de um estado do ser onde os corpos e os nomes, as almas e as ações, o eu e o outro se interpenetram... (VIVEIROS DE CASTRO, 2011, p. 354-355).

Assim, temos no Apocalipse Animal o exemplo de uma narrativa que joga a linguagem mítica aos seus limites. Nela, os personagens da história da salvação são animais que, quando precisam, mudam de forma e assumem funções humanas. A partir da definição de mito feita por Viveiros de Castro, podemos interpretar a literatura visionária como uma porta de acesso às formas seminais da narrativa mítica na qual o humano e o não-humano se 
confundem, mas são igualmente portadores e veículos do divino. Os touros, por exemplo, são humanos na medida em que são identificados metaforicamente com eles, ao mesmo tempo, agem conforme sua natureza animal (pastam, roem seus chifres etc.).

Nos momentos em que o touro se transforma em humano, a narrativa não esclarece que essa mudança é definitiva: "Aquele, nascido touro, se fez homem e fabricou uma grande arca [...]. O touro branco que havia se feito homem saiu da arca, e os três touros com ele" $(89.1,9)$. Do mesmo modo, os astros (anjos?) são animais na medida em que podem copular com eles. Mesmo os próprios animais se apresentam como categorias intercambiáveis, já que novilhas prenhas de astros podem dar à luz elefantes e javalis.

\section{Animalidade e regimes extra-humanos na apocrifia cristã}

À medida em que o tempo passa e a produção literária dos primeiros cristãos avança pelo segundo século da Era Comum, encontramos amostras mais claras da percepção sobre os animais e a Natureza nesses escritos. Se essas percepções são apenas presumidas nos materiais neotestamentários, é na literatura extracanônica que o tema emerge com força e variedade. ${ }^{3}$ Essas experimentações exploram o contato dessa literatura com tendências literárias já bem difundidas no mundo mediterrâneo, entre elas, as formas e temas do folclore e da literatura oral. Além disso, a pseudoepigrafia judaica se soma a esse conjunto contínuo de temas e estruturas narrativas que circulam nos grupos cristãos primitivos (NOGUEIRA, 2015, p. 24-35).

Os temas e enredos folclóricos são fundamentais para compreendermos o desenvolvimento das sensibilidades religiosas dos primeiros cristãos, pois é justamente no folclore que podemos acessar as reminiscências da linguagem mítica, conforme a definimos acima. Nas tradições folclóricas os animais recebem atenção especial. Eles funcionam como mediadores entre os protagonistas dos contos e lendas que circulam no imaginário dos grupos subalternos e, por vezes, seus papéis e características funcionam como extensões dos personagens humanos, como no caso da fábula e do anedotário antigo. Os gêneros narrativos folclóricos se caracterizam, portanto, como desdobramentos da linguagem mítica, preservando, mesmo que apenas em parte, suas características estruturais e motivos recorrentes (CAVALHERI, 2019, p. 28-36).

\footnotetext{
3 Por apócrifos compreendemos o amplo conjunto de materiais literários que, junto ao Novo Testamento, formam a grande rede textual construída pelos cristãos dos primeiros séculos. Essas são fontes especiais para nosso estudo, pois é nesse tipo de produção, popular e de intensa circulação entre grupos subalternos do império romano, que certos temas que começavam a se plasmar nos primeiros escritos cristãos agora se encontram consolidados o bastante para sofrerem experimentações das mais diversas.
} 
Partindo desses pressupostos, podemos começar a traçar um percurso das percepções sobre animalidade e Natureza nos materiais cristãos. A presença animal no Novo Testamento é relativamente pequena. Com exceção do apocalipse joanino, com suas criaturas híbridas e grotescas, a presença animal na literatura canônica se restringe às metáforas e, novamente, às questões dietéticas (por exemplo, na visão de Pedro em At 10). Mesmo assim, um ou outro texto preserva o papel ativo dos animais como instrumentos do propósito divino. É o caso do episódio da entrada de Jesus em Jerusalém, cujo relato, presente nos quatro evangelhos canônicos, destaca a participação do jumentinho no cortejo. Por menor que seja essa referência, veremos a seguir como o tema ganha novas proporções e matizes na literatura apócrifa.

Podemos apontar três topoi recorrentes na literatura relacionados à questão animal e natural:

1. O deserto como lugar de provação e da manifestação do maravilhoso.

2. O companheirismo ou domínio sobre animais selvagens.

3. Metamorfoses e ruptura de fronteiras entre humanos e não-humanos.

Essas três características formam uma espécie de complexo arquetípico, que acompanha os enredos presentes tanto nos evangelhos quanto nos atos apócrifos, e se intensifica nas primeiras hagiografias cristãs.

Comecemos, então, pelos relatos apócrifos da infância de Jesus. Aqui a presença animal, apenas presumida nas narrativas canônicas da natividade, se destaca de maneira especial. O Evangelho do Pseudo-Mateus ${ }^{4}$ trata dos primeiros anos da vida de Jesus, dos antecedentes de seu nascimento a diversos episódios de sua infância. Ao seguirem para o Egito fugindo de Herodes, José, Maria se deparam com prodígios envolvendo os animais. Primeiro, Jesus desce do colo de sua mãe para enfrentar dragões que surgiram em uma gruta onde estavam (18.1). Em seguida, são acompanhados por leões e outras feras selvagens deserto adentro: "Os leões e os leopardos o adoravam e os acompanhavam no deserto; onde José e Maria iam, eles os precediam, mostrando o caminho e inclinando a cabeça; prestando-lhes serviço, faziam festa com a cauda e o adoravam com grande reverência" (19.1). O relato que se segue, contado em primeira pessoa por José, mostra-nos de forma clara a recepção dos temas messiânicos e apocalípticos nesse tipo de narrativa popular:

Os leões caminhavam com eles, com os bois, com os jumentos e com os animais de carga que levavam as coisas necessárias e, mesmo estando juntos, não faziam mal a

A divisão dos capítulos nos evangelhos apócrifos segue a edição de L. Moraldi (1999). 
nenhum deles, mas eram mansos entre as ovelhas e os carneiros que eles tinham levado da Judeia e tinham consigo. Caminhavam entre os lobos e não tinham medo de nada, e nenhum era molesto ao outro. Verificou-se então o que tinha sido dito pelo profeta: os lobos pastarão com os cordeiros. O leão e o boi comeram palha juntos. Com efeito, havia (com eles) dois bois e um carro, no qual levavam as coisas necessárias; ao longo do caminho, guiava-nos os leões (Evangelho do Pseudo-Mateus, 19.2).

Na cena seguinte, Maria, cansada pelo calor do deserto e com sede, pois havia acabado a água de seus odres, se senta à sombra de uma palmeira. Ao ver os cachos da árvore cheios de frutos, Maria diz a José que gostaria de experimentá-los, mas eles não estavam ao seu alcance. No mesmo instante, Jesus ordena à palmeira que se incline para que sua mãe pudesse pegar alguns de seus frutos. Em seguida, Jesus ordena à árvore que abra suas raízes, para dali brotar água fresca e cristalina. Maria e os animais se saciam e juntos dão graças a Deus (20.1-2).

O segundo exemplo se encontra na História de José Carpinteiro. ${ }^{5}$ Mais uma vez, a infância de Jesus é marcada pela presença dos animais selvagens no deserto:

Jesus tinha oito anos quando saiu de Jericó e foi ao Jordão; à beira da estrada, perto da margem do Jordão, havia uma caverna na qual uma leoa alimentava seus filhotes; por isso ninguém podia andar seguro naquela estrada. Jesus, indo de Jericó, sabia que na caverna estava a leoa com seus filhotes; não obstante, entrou na caverna, na presença de todos. Logo que os leões viram Jesus, foram ao seu encontro e o adoraram; Jesus sentou-se na caverna, e os leõezinhos corriam para cá e para lá em torno de seus pés, acariciavam-no e brincavam com ele. Os leões mais velhos ficaram afastados, com a cabeça baixa, adorando-o e fazendo-lhe festa com a cauda (História de José Carpinteiro, 35).

Ao sair da caverna, o povo das redondezas se enche de temor, imaginando que as feras os atacariam ou mesmo devorariam o menino. Ao ver isso, Jesus repreende o povo, dizendo: “Quão melhores do que vós são os animais! Eles conhecem seu Senhor e o glorificam, ao passo que vós, homens, que sois feitos à imagem e semelhança de Deus, o ignorais. As feras me reconhecem e se tornam mansas; os homens me veem e não me reconhecem" (35).

Os dois trechos apresentados podem ser interpretados como a recepção e reelaboração de memórias mais antigas sobre Jesus, no caso, a tentação no deserto, conforme Mc 3, em que Jesus habita entre as feras selvagens que não lhe fazem mal; também de uma enigmática afirmação do Evangelho de Tomé, dito 7, no qual Jesus afirma que "Bem-aventurado o leão comido por um homem: tornar-se-á homem; maldito o homem comido por um leão: o homem se tornará leão”.

Citado da obra editada por Antonio Piñero e Gonzalo del Cerro (2005; 2012). 
No caso dos Atos apócrifos, a relação espaço-humano-animal se acentua consideravelmente. Se, nos evangelhos apócrifos, as feras no deserto agem como adoradores do Messias e servem como modelos de fidelidade a Deus, é nos Atos apócrifos que elas desempenham, além desses papéis, funções determinantes no desenvolvimento das narrativas, especialmente como auxiliadoras da missão apostólica. Existem diversos exemplos ao longo dos cinco atos apócrifos maiores (Pedro, Paulo, João, André e Tomé), mas vamos tratar aqui de apenas três que servem de modelo para narrativas semelhantes.

Nos Atos de Paulo há duas narrativas de martírio em que animais assumem papel central. Na primeira, Tecla, a virgem da cidade de Icônio que parte em uma aventura para encontrar o apóstolo Paulo, é condenada a morrer devorada por feras na arena da cidade. Uma leoa feroz é solta na arena, mas, ao contrário do que esperava a audiência do teatro, a fera defende sua condenada das investidas de outros animais, como leopardos e ursos. A leoa, por fim, sacrifica sua vida para que Tecla não morra nas garras dos outros animais. As mulheres na plateia choram pela morte do animal e ajudam Tecla a se livrar das outras provações às quais é submetida naquele espetáculo de morte (Atos de Paulo e Tecla, 30-35 ). A mesma leoa já havia aparecido em uma cena anterior, atada à Tecla em meio a um cortejo pela cidade, prática comum nos processos de condenação que antecediam os espetáculos no Império Romano.

Ainda nos Atos de Paulo, na seção que narra o martírio do apóstolo na cidade de Éfeso, temos outra vez o tema do encontro entre o santo e animais selvagens no deserto. Chegando à cidade, o apóstolo se encontra com outros irmãos de fé e recorda alguns episódios, entre eles, o do leão que havia batizado:

Quando se fez tarde, fui embora da cidade acompanhado amorosamente por Lemma, a viúva, e sua filha Ammia. Caminhava durante a noite com a intenção de ir a Jericó da Fenícia, e cobrimos grande distância. Quando despontou a aurora, se encontravam atrás de mim Lemma e Ammia, que me tinham um grande afeto, de modo que não fugiram de mim. Então apareceu um leão grande e terrível que saída do Vale dos Ossos. [...] Quando acabei de rezar, a besta havia baixado aos meus pés. Cheio do Espírito Santo, o olhei e disse: - Leão, o que queres? E ele respondeu: - Quero ser batizado. Glorifiquei a Deus que havia dado fala ao animal e a salvação a seu servo. Havia um grande rio naquele lugar, e desci até ele. Então, irmãos, gritei assim: - Tu que habitas as alturas, que tem visto a humildade e tem concedido descanso aos aflitos, que por Daniel fechaste a boca dos leões, que me enviaste a nosso Senhor Jesus Cristo, concede-me... e cumpra-se teu plano que tens decidido a mim. Quando havia terminado esta oração, tomei o leão por sua juba e o mergulhei em água três vezes em nome de Jesus Cristo.

Divisão de capítulos nos Atos apócrifos segue a edição de A. Piñero e G. Del Cerro (2005; 2012). 
Quando saiu da água, agitou sua juba e me disse: - Graça seja contigo. Lhe respondi: - Igualmente contigo. O leão se foi correndo ao campo cheio de alegria (e isto me foi revelado em meu coração). Uma leoa saiu ao seu encontro, mas ele não dirigiu a ela um só olhar, mas escapou correndo (Atos de Paulo, Pap. Bodmer, 6-9, tradução nossa).

Mais à frente, Paulo e o leão voltam a se encontrar, dessa vez na condenação do apóstolo à morte na arena. Ali, ambos se reconhecem e se saúdam como cristãos, para o maravilhamento e espanto da plateia. No diálogo, Paulo pergunta ao animal como ele havia chegado ali, e como resposta o leão afirma: "assim como você, Paulo". Após serem livrados por Deus de mais alguns perigos, Paulo e a fera conseguem fugir da cidade.

Por fim, o último exemplo nos Atos apócrifos se encontra nos Atos de Pedro. O enredo da narrativa é simples: Pedro, ao ficar sabendo de problemas com a igreja em Roma, se dirige à cidade, onde fica sabendo que Simão Mago persuadiu os cristãos dali com seus sortilégios. Pedro, entre curas, exorcismos e outras situações, acaba enfrentando e derrotando publicamente seu adversário. Um episódio que se destaca na estória é o do cachorro falante.

Ao saber que Simão Mago se escondia na casa de Marcelo, senador que havia se convertido à fé no Cristo, Pedro se dirige ao local para desafiá-lo e, assim, desmascará-lo diante da cidade. Simão, presumindo a atitude de Pedro, coloca um guarda nos portões da casa para impedi-lo de entrar. Diante da situação, Pedro liberta o cão de guarda da casa e o ordena que entre no local e lance o desafio ao mago. A situação, que beira o cômico, se desenrola da seguinte maneira ${ }^{7}$ :

Pedro se voltou ao povo que o seguia e disse: - Vão contemplar um grande e maravilhoso prodígio. Pedro olhou um enorme cão que estava atado por uma grande corrente, se aproximou dele e o soltou. Quando estava livre, o cão tomou voz humana e disse a Pedro: - Que me ordenas fazer, servo do Deus vivo e inefável? Pedro respondeu: Entre e diga a Simão em meio aos que o rodeiam: "Pedro lhe diz assim: mostre-se em público, pois por tua causa, malvado e corruptor das almas simples, ele veio a Roma". O cão se pôs a correr de imediato e entrou impetuosamente entre os que cercavam Simão, levantou as patas dianteiras e disse com um enorme vozeirão: - Tu, Simão: assim te diz Pedro, o servo de Cristo, que está à porta: Mostra-te em público; pois por ti ele veio a Roma, malvadíssimo e sedutor das almas simples. Simão, ao ouvi-lo e ao contemplar essa visão incrível, se acabaram as palavras com as quais seduzia os presentes, diante do espanto de todos. [...] Simão, dentro da casa, respondeu ao cão: - Diga a ele que não estou em casa. Mas o cão respondeu diante de Marcelo: - Malvadíssimo, desavergonhado e inimigo de todo ser vivente que crê em Cristo. A ti tem sido enviado um animal mudo que recebeu voz humana para te confundir e comprovar que é um

\footnotetext{
A cena é interrompida no final do capítulo 9 e retomada no início do capítulo 12. Na citação decidimos
} mostrar as duas cenas em sequência. 
mentiroso e enganador. Tantas horas tens refletido para chegar a dizer: "Diga que não estou aqui”"? Não te envergonhas de emitir tua voz, tão débil e inútil, contra o ministro e apóstolo de Cristo, Pedro, como se pudesses passar inadvertido diante dele que me enviou a falar diante de tua face? Mas tudo isso não é por tua causa, mas por aqueles a que seduzias e lançavas à perdição. Maldito sejas, inimigo e corruptor do caminho à verdade de Cristo! Este castigará com fogo imortal as iniquidades que perpetraste e permanecerás nas trevas exteriores! (Atos de Pedro, 9.4-7; 12.1-2, tradução nossa).

Em todos os exemplos descritos encontram-se características comuns. A primeira que podemos destacar é a do reconhecimento animal à santidade do protagonista. Nos evangelhos da infância, os animais do deserto não apenas reconhecem, mas também se colocam em posição de submissão a Jesus. Nos Atos de Paulo, as narrativas de martírio de Paulo e Tecla apresentam em comum a compaixão das bestas no momento da execução. Especialmente no caso do martírio em Éfeso, o primeiro encontro de Paulo com o leão falante se dá em sua viagem ao deserto (Paulo, inclusive, encontra o leão na mesma região que Jesus, próximo a Jericó). Mesmo que a capacidade de falar diferencie os animais de Paulo e Tecla, a disposição ao testemunho e a proximidade entre animal e humano enquanto vítimas da mesma situação é um ponto em comum. Quanto ao último exemplo, ao ganhar a capacidade de falar, o cão dos Atos de Pedro também declara sua devoção e compromisso a Cristo e ao apóstolo. Na casa de Marcelo, ao confrontar Simão, o cão imposta sua voz e se ergue em duas patas, como que assumindo "postura humana".

De acordo com Laura Hobgood-Oster, há um grande conjunto de sensibilidades religiosas em jogo por trás dessas narrativas. Enquanto, em certos registros, cristãos estão discutindo a racionalidade animal e os tabus que os envolvem na vida ética, o universo da religião popular desenvolve sua "teologia natural" de outro modo: os animais são veículos conscientes da presença divina, a quem manifestam devoção de várias maneiras (batismo, confissão ou martírio). Desse modo, a diferença ontológica entre humano e animal é mitigada, quando não completamente negada (HOBGOOD-OSTER, 2008, p. 61). Lembrando das palavras de Jesus na História de José Carpinteiro, as feras do deserto reconhecem e adoram o Senhor antes mesmo dos humanos. Nas tradições cristãs populares, animais são exemplos de piedade e veículos da revelação divina.

Contudo, se os animais são dotados de tais qualidades, qual a necessidade de se prescindir de um humano para que elas sejam expressadas ou publicamente reconhecidas? Ángel Narro, ao analisar o tema dos "senhores dos animais" (despótes therón) no cristianismo primitivo, aponta o retorno utópico à harmonia natural como o fundamento dessa relação. Jesus e os 
apóstolos são figuras que encarnam o arquétipo do "mediador" entre o divino e o humano, ao mesmo tempo em que são reconhecidos como "homens divinos", agentes religiosos capazes de "operar esse tipo de prodígios e materializar pontualmente essa paz paradisíaca do projeto divino original" (NARRO, 2015, p. 191).

Um último ponto a ser abordado diz respeito à relação tempo-espaço nessas narrativas. Não se trata de se discutir o desenvolvimento narrativo a partir dessas categorias literárias, à maneira do "cronotopo" bakhtiniano. ${ }^{8} \mathrm{~A}$ relação entre tempo e espaço aqui se dá a partir de uma interação particular que os personagens possuem com a própria Natureza. Virginia Burrus, em seu estudo sobre as hagiografias antigas, afirma que o tempo do santo é o “tempo animal". Afinal de contas, um dos elementos centrais de uma narrativa hagiográfica está na recusa do santo em assumir certos papeis sociais que lhes são impostos, para assim poder viver de maneira ascética. Apesar de Burrus analisar especificamente as hagiografias dos chamados "Pais e Mães do Deserto", suas observações podem muito bem servir para as narrativas dos evangelhos e atos apócrifos, ao menos nas seções que destacamos aqui.

O primeiro elemento que Burrus destaca é a ruptura do tempo social. O tempo do santo é um "tempo animal", pois a ruptura do ciclo desejado da vida adulta, com as responsabilidades do matrimônio, do trabalho e da geração da prole é substituída pelo tempo da espera e da simplicidade que marca suas experiências religiosas. O tempo do santo é definido pela própria Natureza, e ele próprio se torna sujeito e objeto dela. Ao não assumir esses papéis, o santo coloca-se em uma condição de permanente fragilidade, agindo segundo a necessidade de sua sobrevivência ou conforme a espera necessária de seu sustento. Nesse sentido, o deserto, esse local de privação, animaliza o santo que, por sua vez, é reconhecido como sujeito e objeto do meio (BURRUS, 2019, p. 95-100).

As manifestações animais ocorrem - nos evangelhos da infância e nos atos apócrifos - em locais ermos (com exceção, é claro, do cão falante de Pedro). Os apóstolos rompem com a normatividade do tempo social, deslocando-se para pregar o evangelho. De igual modo, a ruptura desses papeis os fazem estranhos por onde passam. Paulo, o apóstolo que prega a castidade, enquanto Tecla rompe compromissos matrimoniais para viver integralmente a Deus. É na infância que Jesus é reconhecido como Senhor de dragões e leões, também no deserto de Jericó.

8 O conceito de "cronotopo" foi cunhado pelo teórico russo Mikhail Bakhtin (1895-1975), e designa as relações entre espaço e tempo na organização e desenvolvimento do discurso literário. 


\section{Considerações finais}

Retomando as considerações de Philipe Descola e Eduardo Viveiros de Castro, a distinção entre Natureza e Cultura, conforme o pensamento moderno, não dá conta de compreender a complexa relação das sociedades ameríndias, principalmente no modo como seus membros se compreendem em relação à totalidade de seres, animados ou inanimados, que compõe sua cosmologia. Diante do que foi levantado a respeito da literatura cristã primitiva, poderíamos propor que, à semelhança das mitologias ameríndias, as formas populares de expressão religiosa dos primeiros cristãos nos fornecem elementos para postularmos sua compreensão de mundo de modo diferente da grande tradição que se estendeu por séculos, fundamentada em certa "teologia do domínio" que sempre tomou o humano como pináculo da criação divina, como uma categoria superior e desatada do resto de todo o cosmo.

Nas fontes apócrifas é possível perceber as nuances de um imaginário que horizontaliza as relações entre corpos e espaços, fazendo com que animais, humanos e seres sobrenaturais compartilhem funções e representações entre si. No caso específico dos animais, sua função religiosa excede o mero simbolismo e alegoria, apontando para um papel ativo como sujeitos religiosos, tão centrais quanto os humanos para a construção religiosa de seu mundo. Os apóstolos, santos e o próprio menino Jesus são, retomando a expressão de Bataille, como "água na água”: observando um mundo onde animais, humanos, paisagens, plantas, anjos e outras formas de existência compartilham do mesmo poder criativo e interativo, acessível a partir da experiência religiosa e suas expressões literárias.

\section{Referências bibliográficas}

BATAILLE, Georges. Teoria da religião: seguida de Esquema de uma história das religiões. Belo Horizonte: Autêntica, 2016.

BÍBLIA DE JERUSALÉM. Nova edição, revista e ampliada. São Paulo: Paulus, 2002.

BURRUS, Virginia. Ancient Christian ecopoetics: cosmologies, saints, things. Philadelphia: University of Pennsylvania Press, 2019.

CAVALHERI, Guilherme de Figueiredo. Heróis e feras na arena: folclore e imaginário animal nos Atos Apócrifos de Paulo. 2019. Dissertação (Mestrado em Ciências da Religião) - Escola de Comunicação, Educação e Humanidades, Universidade Metodista de São Paulo, São Bernardo do Campo.

DESCOLA, Philippe. Outras naturezas, outras culturas. São Paulo: Editora 34, 2016.

HOBGOOD-OSTER, Laura. Holy dogs and asses: animals in the Christian tradition. Urbana; Chicago: The University of Illinois Press, 2008. 
LIBRO 1 DE HENOC. Trad. F. Corriente e A. Piñero. In: MACHO, Alejandro Diez (Ed.). Apocrifos del Antiguo Testamento. Tomo IV: Ciclo de Henoc. Madrid: Ediciones Cristiandad, 1984.

MACIEL, Lucas da Costa. Perspectivismo Ameríndio. In: Enciclopédia de antropologia.

São Paulo: Universidade de São Paulo, Departamento de Antropologia. Disponível em: $<$ http://ea.fflch.usp.br/conceito/perspectivismo-amer\%C3\%ADndio $>$. Acesso em: 27 fev. 2020 .

MATTHEWS, Christopher R. Articulate animals: a multivalent motif in the apocryphal acts of the apostles. In: BOVON, François; BROCK, Ann Graham; MATTHEWS, Christopher R. (Ed.). The apocryphal acts of the apostles. Cambridge: Harvard University Press, 1999 (Harvard Divinity School Studies).

MORALDI, Luigi. Evangelhos apócrifos. São Paulo: Paulus, 1999.

NARRO, Ángel. Ecos de la pótnia y el depótes therón em los cinco principales Hechos apócrifos de los apóstoles. Minerva, n. 28, p. 185-220, 2015.

NODARI, Alexandre. A literatura como antropologia especulativa. Revista Antropoll, n. 38, p. 75-85, Jan./Jun. 2015.

NOGUEIRA, Paulo Augusto de Souza. Apocrificidade: os apócrifos no estudo do cristianismo primitivo. In: NOGUEIRA, Paulo Augusto de Souza (Org.) Apocrificidade: o cristianismo primitivo para além do cânon. São Paulo: Fonte Editorial, 2015.

PIÑERO, Antonio; DEL CERRO, Gonzalo (Ed.). Hechos apócrifos de los apóstoles I: Hechos de Andrés, Juan y Pedro. Madrid: Biblioteca de Autores Cristianos, 2012.

PIÑERO, Antonio; DEL CERRO, Gonzalo (Ed.). Hechos apócrifos de los apóstoles II: Hechos de Pablo y Tomás. Madrid: Biblioteca de Autores Cristianos, 2005.

SUSIN, Luiz Carlos; ZAMPIERI, Gilmar. A vida dos outros: ética e teologia da libertação animal. São Paulo: Paulinas, 2015.

VIVEIROS DE CASTRO, Eduardo. A inconstância da alma selvagem - e outros ensaios de antropologia. São Paulo: Cosac Naify, 2011.

VIVEIROS DE CASTRO, Eduardo. Metafísicas canibais: elementos para uma antropologia pós-estrutural. São Paulo: N-1 Edições; Ubu, 2018.

WALDAU, Paul. Animals. In: TAYLOR, Bron R. (Ed.). The encyclopedia of religion and nature. London; New York: Thoemmes Continuum, 2005. v. 1.

Submetido em: 27-2-2020

Aceito em: 5-5-2020 